\title{
Oviposition site selection of a threatened moth Eriogaster catax (Lepidoptera: Lasiocampidae) in agricultural landscape-implications for its conservation
}

\author{
Marcin Kadej ${ }^{1}$ (D) $\cdot$ Krzysztof Zając $^{1} \cdot$ Dariusz Tarnawski $^{1}$
}

Received: 22 May 2017 / Accepted: 22 November 2017 / Published online: 1 December 2017

(c) The Author(s) 2017. This article is an open access publication

\begin{abstract}
Shrubby field margins and hedgerows play an important role for many species of flora and fauna in agro-ecosystems, including those which are rare or endangered. A characteristic species of these semi-natural habitats in agricultural landscape is the Eastern eggar, Eriogaster catax (Linnaeus, 1758): a moth species threatened in many European countries. In this study we investigated the oviposition preferences of E. catax at host plant level in agricultural landscape in south-western Poland, near of the northern limit of the species distribution in Europe. In total we surveyed 796 host plants. Altogether we found 439 eggs batches or caterpillar webs of E. catax on 373 occupied plants. Most of them (92.3\%) were on blackthorn Prunus spinosa, which was preferred host plant next to pear Pyrus spp. However, the most important predictor of the presence of egg batches were microclimatic conditions. We recorded that females preferred host plants exposed to direct sunlight and with south and west-facing slopes for oviposition and avoided those inside of the dense shrub canopy. Eggs were laid more often on the trunk and on the upper half of the host plant, however there was a significant difference in vertical and horizontal position of egg batches in relation to the position of the plant. Inside of the shrub canopy, eggs were laid in higher parts of host plant and closer to the trunk, than at the edge and on solitary plants. Based on our observations the management strategies for the habitats of the species are proposed and discussed.
\end{abstract}

Keywords Egg-laying $\cdot$ Female preference $\cdot$ Field margins $\cdot$ Hedgerows $\cdot$ Host plant $\cdot$ Micro-climate $\cdot$ Species conservation

\section{Introduction}

About a half of total land surface of Europe is occupied by agricultural land, thus agriculture has a great importance for biodiversity conservation (Henle et al. 2008; Halada et al. 2011). However, farmland habitats have shown the largest decrease in species population index between 1970 and 2000 at pan-European scale (de Heer et al. 2005). One of the main causes of the decline of farmland biodiversity, worldwide, is agricultural intensification (Matson et al. 1997; Tscharntke et al. 2005), leading to a loss of ecological heterogeneity at multiple spatial and temporal scales (Benton et al. 2003). However, the drivers of population changes

Krzysztof Zając

krzysiek.zajac3@gmail.com

1 Department of Invertebrate Biology, Evolution and Conservation, Faculty of Biological Science, Institute of Environmental Biology, University of Wrocław, Przybyszewskiego 65, 51-148 Wrocław, Poland of many farmland species could differ across Europe (Reif et al. 2008; Tryjanowski et al. 2011). In Poland, where about $61 \%$ of total area is covered by farmland, nearly half of the more than 2.5 million farms are still smaller than 2 ha, and the rural landscape is relatively rich in a dense network of semi-natural field margins (Wuczyński et al. 2011). However, in the last few years, these agricultural structures and related habitats have been severely threatened in Poland and other countries of Central and Eastern Europe, by abandonment, afforestation or agricultural intensification (Stoate et al. 2009). One of these types of semi-natural habitats are shrubby margins and hedgerows bordering with pastures, meadows or cultivated fields. These structures are recognized as especially important elements for both flora and fauna in agro-ecosystems, providing a habitat, refuge or serving as corridors for many species, including those which are rare and endangered (Forman and Baudry 1984; Dover and Sparks 2000; Zechmeister et al. 2002; Wehling and Diekmann 2009; Wuczyński et al. 2011, 2014). 
One of the species associated to agricultural landscapes with semi-natural shrubby vegetation and hedgerows is Eriogaster catax (Linnaeus, 1758) (Lepidoptera: Lasiocampidae). It is a threatened moth listed in the EU Habitats Directive (Council of the European Communities 1992) as a Species of Community Interest, whose conservation requires the designation of Special Areas of Conservation and which needs strict protection. The last assessment of this species for the period 2007-2012 revealed unfavourable conservation status in the majority of EU Member States (EIONET 2014). In Poland, the number of known locations of $E$. catax has increased significantly since 2007; however, this improved knowledge is related to a growing interest in this species rather than a true recovery of its populations across Poland (Oleksa 2012). Despite the prevalence of its potential habitats such as blackthorn scrub throughout the country, the species occurs only locally, as in many other countries. It seems that the reasons for this should be an increase of ecological assessments of the species. However we still lack sufficient knowledge about what environmental factors determine the occurrence of the species and limit its abundance.

Despite a quite wide distribution of the species across Europe and Asia, its protected status and unfavourable or unknown prospects for long term survival in many European countries, so far relatively little attention has been paid to its life history and ecology. Most of the current knowledge about the biology and habitat preferences of this species is based on a few published papers (Bolz 1998; Ruf et al. 2003; Dolek et al. 2008), as well as on unpublished studies (Höttinger 2005; Valchářová 2012). Many of the published papers are devoted mainly to the geographical distribution of $E$. catax, with only some general remarks on its ecology (Oleksa 2002; García-Pérez et al. 2009; Baillet 2013; Chrzanowski et al. 2013; Kuźmiński et al. 2014; Bury 2015).

The development of effective conservation strategies and management of $E$. catax across its geographical range, should be based on a detailed knowledge about the species habitat requirements at local scales (Anthes et al. 2008; Čelik et al. 2015). Understanding of a species' oviposition preferences may be of crucial importance, because oviposition itself represents the spatial inference between all successive life stages and the environment (Čelik 2013). Oviposition site choice is a life-history trait of critical importance, because a female's decision can have serious consequences for her own reproductive fitness, by affecting the embryo survival, juvenile performance and offspring phenotype (Refsnider and Janzen 2010). Importantly, a species' habitat requirements may differ within its distribution range. Sometimes, the host plant preference may vary at a small, even a few kilometres scale (Kuussaari et al. 2000). The immature stages are often more susceptible to negative or inappropriate management than adults, because of their lower mobility
(Merckx and Berwaerts 2010), and thus the knowledge about local oviposition preferences of the species may be essential for effective conservation management.

The main objective of this study was to determine the oviposition site selection by E. catax at the host plant level and to consider implications of results for the conservation of the species. Our study is the first on this species using an information-theoretic approach (sensu Burnham and Anderson 2002) to assess the relative importance of the host plant parameters for ovipositing female's decision. The study sites were located in agricultural landscape near of the northern limit of the species distribution in Europe and so we assume that our results may not reflect the situation in other regions within the species' range. Therefore, we also compared our findings with other studies (published and unpublished), conducted often in another type of habitat, to assess variation in oviposition preferences across the species' range.

\section{Materials and methods}

\section{Study species}

The Eastern eggar, E. catax (Linnaeus, 1758) (Lepidoptera: Lasiocampidae), is distributed from Northern Spain through Central and Southern Europe to Russia and Western Asia (Oleksa 2012). Generally, it is restricted mainly to warmer parts of the West Palaearctic, and its distribution is mostly island-like (disjunctive). Moreover, the species shows regressive tendency in many European countries. The species is classified as strictly protected in many European countries, including Poland. It is classified by the IUCN under DD category (Deficient Data) (World Conservation Monitoring Centre 1996), while in the Polish Red Book of Animals it has a status of VU (Vulnerable) (Oleksa 2004).

Eriogaster catax is a thermophilic species found in warm and relatively humid habitats such as sparsely-wooded, open forests, and woodland edges, as well as hedges and other shrubby sites along the roadsides and field margins, on the hills, steep slopes, and banks of gullies or even on railway embankments. Adults fly in the autumn (September-October), with females laying their full egg complement in one clutch on the trunk or branches of the host plant covered by a layer of gray black hairs from the female's abdomen. The eggs overwinter with the young caterpillars hatching in midApril. They live in webs which are built directly on the host plant. They feed on a variety of deciduous trees and shrubs including blackthorn Prunus spinosa, hawthorn Crataegus spp., pear Pyrus spp., oak Quercus spp., birch Betula spp., poplar Populus spp., elm Ulmus spp. and roses Rosa spp. In Spain they also feed on the herbaceous perennial plant Dorycnium pentaphyllum. It is important to note, however, that the diet of young larval (instars L1-L3) is restricted 
mainly to Prunus spp. and Crataegus spp., whilst older caterpillars have a wider spectrum of food plants (i.e. they are polyphagous) and can feed on the above mentioned species of trees. The caterpillars stop feeding by the end of May. Pupation take place in a cocoon, which is most often situated on the ground in leaf litter at the base of host plants, or in their surrounding area (Freina 1996; Bolz 1998; Ruf et al. 2003; García-Pérez et al. 2009; Oleksa 2012; Bury 2015).

\section{Field surveys}

Field surveys were carried out in 2015 and 2016 at 11 sites in Odra River Valley, south-western Poland (Fig. 1), with annual precipitation of ca. $600 \mathrm{~mm}$ and an average annual temperature of $8.5^{\circ} \mathrm{C}$ (Głowicki et al. 2005). It is one of the most important refuges of E. catax in Poland (Oleksa 2012; Chrzanowski et al. 2013). Hedgerows or patches with scattered potential host plants separated by less than $100 \mathrm{~m}$ were treated as one site. The minimum distance between the study sites was $150 \mathrm{~m}$, maximum- $32 \mathrm{~km}$. Basic characteristics of each study site are listed in Table 1.

Each site was searched for egg batches twice a year, first from early February to the end of March, and again between 20th and 30th April. The second survey coincided with time of appearance of the larval web to facilitate the location of previously undetected egg batches. We counted the number of egg batches on each host plant. A single plant was defined as a trunk with its branches. To avoid duplicate counting, all batches of eggs were marked with a ribbon.

For each plant, both occupied as well as randomly selected unoccupied, we recorded/measured the following variables: (1) plant species, (2) height of the plant (in $\mathrm{cm}$ ),
(3) trunk diameter at $20 \mathrm{~cm}$ above the ground, (4) plant position (three categories: 'edge', 'interior' and 'solitary' for host plants growing, respectively, at the border, inside, and outside of dense shrub canopies), (5) sun exposure (two categories: 'full sun', 'shady') and (6) aspect (eight categories: $\mathrm{N}$, NE, E, SE, S, SW, W, NW). For modelling purposes, aspect was converted into a continuous variable as 'northness' - $\cos (($ aspect*pi $) / 180)$, and 'eastness' $-\sin (($ aspect*pi $) / 180)$ representing, a north-south and east-west exposure gradient, respectively(Guisan et al. 1999), whose values varied from -1 (south and west) to 1 (north and east).

For egg-bearing plants we also determined the oviposition height above the ground (in $\mathrm{cm}$ ) and the distance of the egg batches from the trunk (measured as straight line from batches to trunk, in $\mathrm{cm}$ ).

\section{Statistical analysis}

All statistical analyses were performed in R statistical software version 3.3.0 (R Core Team 2016). Oviposition preferences of $E$. catax were examined using a generalized linear mixed model (GLMM) with logit-link function and binomial error variance with the package lme4 (Bates et al. 2015). The binary dependent variable was coded as 1 (plant with egg batches) and 0 (plant without egg batches). The site was treated as a random factor. Before inclusion in the model, collinearity among fixed variables was tested using Spearman rank correlation matrix $\left(\mathrm{r}_{\mathrm{S}}\right)$ and variance inflation factors (VIF) (Zuur et al. 2010; Dormann et al. 2013). As an acceptable level of collinearity we assumed $r_{S}<10.7 \mid$ and VIFs $<4$. The variance inflation factor was calculated using the 'vif.mer' function (downloaded from https://github.com/

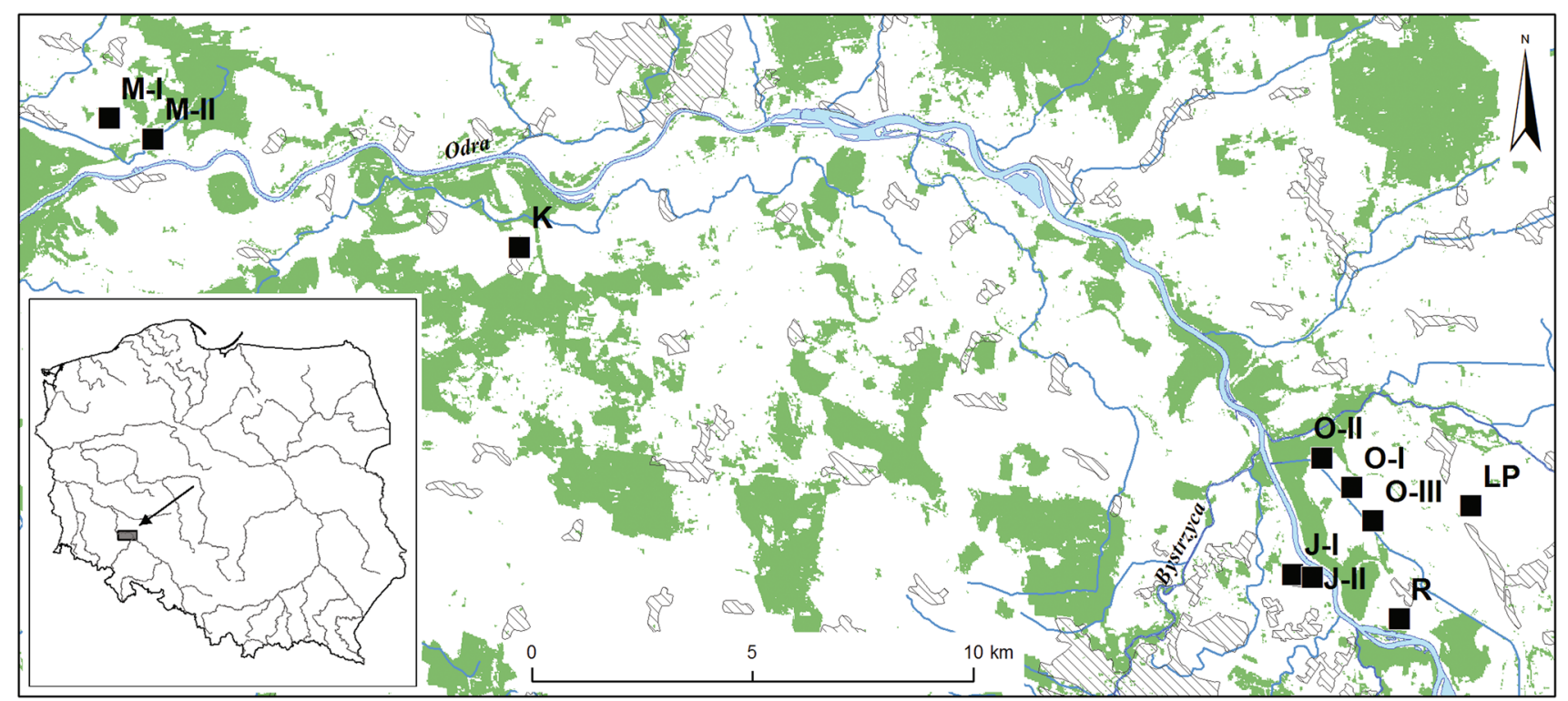

Fig. 1 Location of the study sites in the Odra River Valley, SW Poland. Labels of the study sites correspond to those given in Table 1 


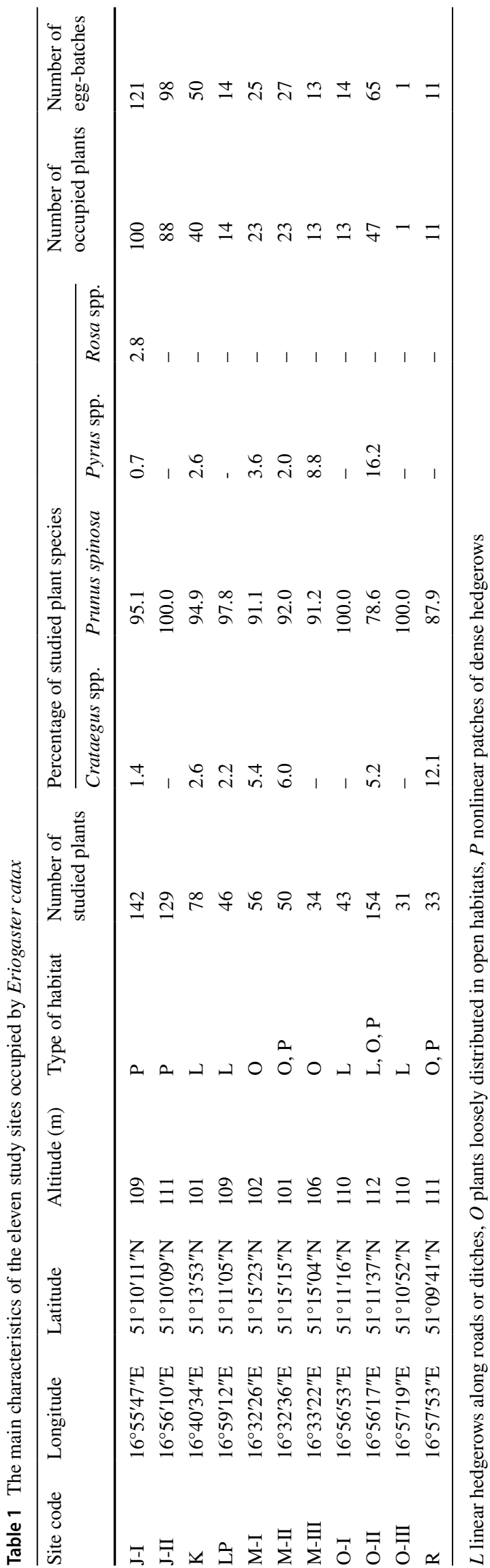

aufrank/R-hacks/blob/master/mer-utils.R, May 2016) in R. Because of the high correlation between the height of plant and trunk diameter (Spearman rank correlation $\mathrm{r}_{\mathrm{S}}=0.752$, $P<0.001)$ we used in modelling only the first variable. For the final model we included six fixed variables: plant position, sun exposure, plant species, plant height, northness and eastness with all VIFs between 1.08 and 3.64.

As the predictors used in regression model were on different scales, all continuous variables were standardized using Gelman's approach (Gelman 2008), using the 'standardize' function within the arm package (Gelman and Su 2015). It allowed a direct comparison of beta estimates-larger values of betas indicate stronger relationships between explanatory and dependent variables. The categorical and binary predictors were left unchanged.

To identify the most parsimonious models explaining variation in egg deposition pattern we performed a model selection procedure based on information theory approach and the corrected Akaike information criterion (AICc) (Burnham and Anderson 2002). All potential models containing random factor and any subset of explanatory factors were fitted to the data and were ranked according to $\Delta \mathrm{AICc}$ (the difference between the AIC of the best model and the compared model). Models with $\Delta \mathrm{AICc} \leq 2$ were considered as equally good (Burnham and Anderson 2002). Thereafter, Akaike weights $\left(w_{i}\right)$ were calculated for each model. To derive parameter estimates ( $(B)$ we used model averaging over $95 \%$ confidence set based on cumulative Akaike weights (Burnham and Anderson 2002). We used the so-called natural average method, where parameters are averaged only across models they occur in (Burnham and Anderson 2002). Only beta coefficients where the $95 \%$ confidence intervals (95\% CIs) that did not overlap with zero were considered as significant (Grueber et al. 2011). All model comparisons and model averaging were performed in the MuMIn package (Bartoń 2016).

To investigate how much variation was explained by final models, we calculated both the marginal and conditional

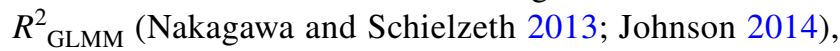
using 'r.squaredGLMM' function in the MuMIn package (Bartoń 2016). The marginal $R^{2}\left(R^{2} m\right)$ value shows the proportion of the variance explained only by the fixed effects, while the conditional $R^{2}\left(R^{2} c\right)$ value shows the proportion of the variance in the raw data explained by entire model, including both fixed and random effects.

To quantify the relative variable importance of each explanatory variable we used the sum of Akaike weights (SW) for all models (Burnham and Anderson 2002; Giam and Olden 2016, but see; Galipaud et al. 2014; Cade 2015). In addition, we used hierarchical partitioning to calculate an estimate of the independent effect of each explanatory factor present in the best models on response variables (Chevan and Sutherland 1991). Subsequently, we determined the 
statistical significance of the independent effect of each variable using a randomization test $(n=100)$ based on an upper confidence limit of 0.95 (a pseudo z-scores $>1.65$ ). We performed the hierarchical partitioning analyses using the 'hier. part' and 'rand.hp' functions in the hier.part package (Walsh and Mac Nally 2013).

Differences in vertical and horizontal position of egg batches in relation to the position of the host plant were analyzed using a Kruskal-Wallis test with Mann-Whitney tests for post-hoc paired comparisons. A polar plot was performed with package plotrix (Lemon 2006).

\section{Results}

In total we counted 796 potential host plants in eleven sites. Altogether we found 439 egg batches of E. catax on 373 occupied plants. The vast majority of them was found on P. spinosa $(\mathrm{N}=405,92.3 \%)$. The other were on Pyrus spp. $(\mathrm{N}=25,5.7 \%)$, Rosa spp. $(\mathrm{N}=5,1.1 \%)$ and Crataegus spp. $(\mathrm{N}=4,0.9 \%)$. Usually, there was only one batch of eggs on each occupied plant (Fig. 2). We found more than one batch per plant on $P$. spinosa (range: 1-6 batches/plant), Rosa spp. (range: $2-3$ batches/plant) and Pyrus spp. (range: 1-3 batches/plant). The length of egg batches varied from 3.5 to $46 \mathrm{~mm}$ (median $=28.6 \mathrm{~mm}, 1$ st and 3nd quartile: $23.5 \mathrm{~mm}$ and $33.3 \mathrm{~mm}, \mathrm{~N}=276$ ). Females of $E$. catax mostly laid their eggs on live branches or trunks. We found only 12 batches of eggs $(2.7 \%)$ on dead branches or completely dead plants (seven on $P$. spinosa and five on Rosa spp.) Rose shrubs were not recorded as host plants for caterpillars in the study area, as the larvae moved to nearby branches of $P$. spinosa after hatching.

The model selection based on Akaike's criterion showed that two models explaining presence of eggs were equally good (Table 2). Explanatory variables present in these models included all used predictors, despite a significant relationship was only between the presence of the eggs of E. catax and the northness, eastness, sun exposure, plant species and plant position (Table 3). The summed Akaike weights (RVI) for all candidate models suggest that these variables are also the most important predictors of oviposition site selection. Probability of egg laying by females decreased with north- and east-facing exposure of the host plant (Table 3). In our study sites, most of the occupied plants were oriented toward to south $(27 \%)$, south-east (25\%) or south-west (22\%) (Fig. 3). Moreover, shaded plants and those located inside of the dense shrub canopy were avoided by ovipositing females. The probability of laying eggs on P. spinosa and Pyrus spp. was also higher than on the Crataegus spp. or Rosa spp. (Table 3). Because the confidence interval for estimate of the plant height includes

Fig. 2 Number of egg-batches of Eriogaster catax per host plant, in the study sites in SW Poland

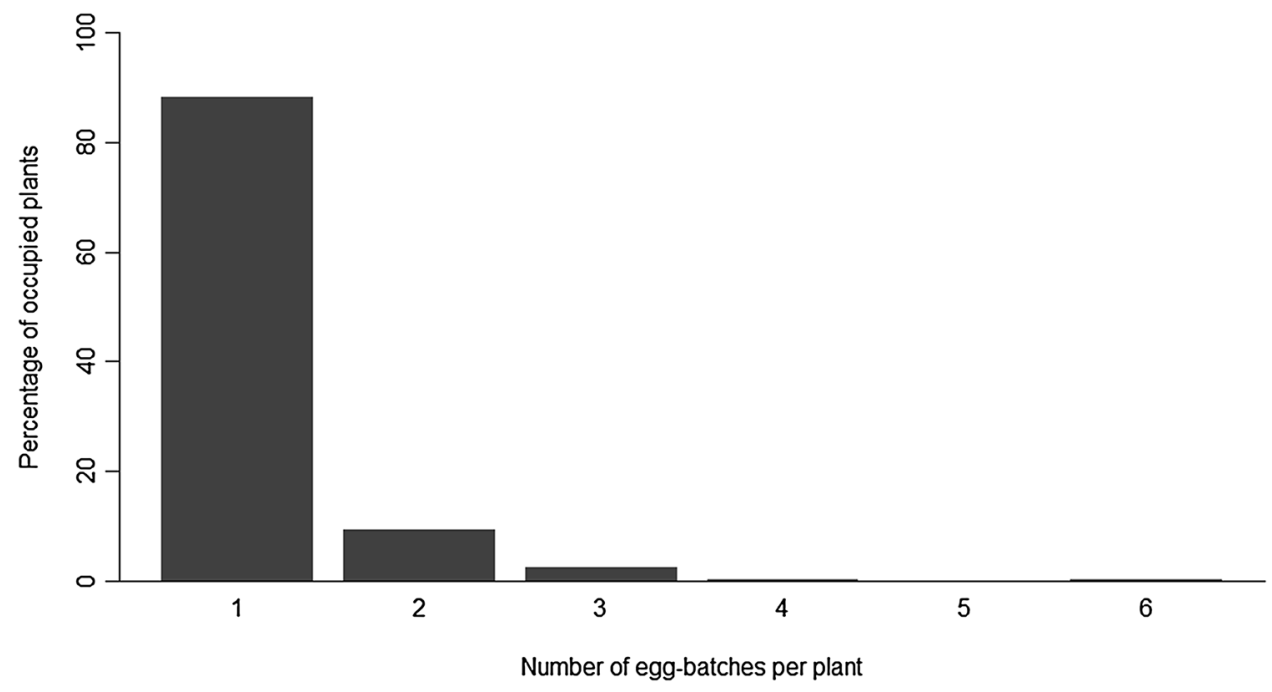

Table 2 Best generalized linear models describing the occurrence of the egg-batches and larval webs of the Eriogaster catax on host plant; $d f$ the number of parameters in a model, $\triangle A I C c$ differences between

AICc of a model and the best AICc, $w_{i}$ Akaike's weight of the model, $R^{2} m$ marginal $\mathrm{R}^{2}, R^{2} c$ conditional $\mathrm{R}^{2}$

\begin{tabular}{|c|c|c|c|c|c|c|c|}
\hline No & Model & $\mathrm{df}$ & $\mathrm{AICc}$ & $\triangle \mathrm{AICc}$ & $\mathrm{w}_{\mathrm{i}}$ & $\mathrm{R}^{2} \mathrm{~m}$ & $\mathrm{R}^{2} \mathrm{c}$ \\
\hline 1 & Eastness + exposure + plant.position + northness + plant.spec & 10 & 915.49 & 0.00 & 0.56 & 0.20 & 0.34 \\
\hline 2 & $\begin{array}{l}\text { Eastness + exposure + plant.height + plant.position + north- } \\
\text { ness + plant.spec }\end{array}$ & 11 & 917.10 & 1.62 & 0.25 & 0.20 & 0.35 \\
\hline
\end{tabular}


Table 3 Averaged estimates of the function slopes and relative importance of the variables (RVI) present in the most parsimonious GLMMs describing the oviposition site selection by Eriogaster catax

\begin{tabular}{|c|c|c|c|c|c|}
\hline Variable & Estimate & SE & $\begin{array}{l}\text { Lower 95\% } \\
\text { CL }\end{array}$ & $\begin{array}{l}\text { Upper 95\% } \\
\text { CL }\end{array}$ & RVI \\
\hline (Intercept) & -1.363 & 0.746 & -2.827 & 0.101 & \\
\hline $\begin{array}{l}\text { z.northness } \\
\text { sun.exposure }\end{array}$ & -1.389 & 0.206 & -1.793 & -0.985 & $\begin{array}{l}1.00 \\
1.00\end{array}$ \\
\hline : shaded ${ }^{*}$ & -1.178 & 0.207 & -1.584 & -0.771 & \\
\hline plant.position & & & & & 0.97 \\
\hline$:$ interior $^{\dagger}$ & -0.786 & 0.243 & -1.262 & -0.309 & \\
\hline $\begin{array}{l}: \text { solitary }{ }^{\dagger} \\
\text { plant.species }\end{array}$ & -0.152 & 0.285 & -0.711 & 0.407 & 0.94 \\
\hline $\begin{array}{l}\text { Prunus spi- } \\
\text { nosa\# }\end{array}$ & 1.716 & 0.611 & 0.516 & 2.917 & \\
\hline Pyrus spp.\# & 1.513 & 0.686 & 0.166 & 2.860 & \\
\hline Rosa spp. & 0.147 & 1.199 & -2.207 & 2.501 & \\
\hline z.eastness & -0.467 & 0.188 & -0.836 & -0.098 & 0.89 \\
\hline z.plant height & 0.139 & 0.210 & -0.273 & 0.551 & 0.30 \\
\hline
\end{tabular}

Site was used as random effect with a variance of 0.736 and a standard deviation of 0.858 . Parameters estimates for the predictors with significant effect are bolded

* 'full sun' was the reference category

$\dagger$ 'edge' was the reference category

${ }^{\#}$ Crataegus spp. was the reference category

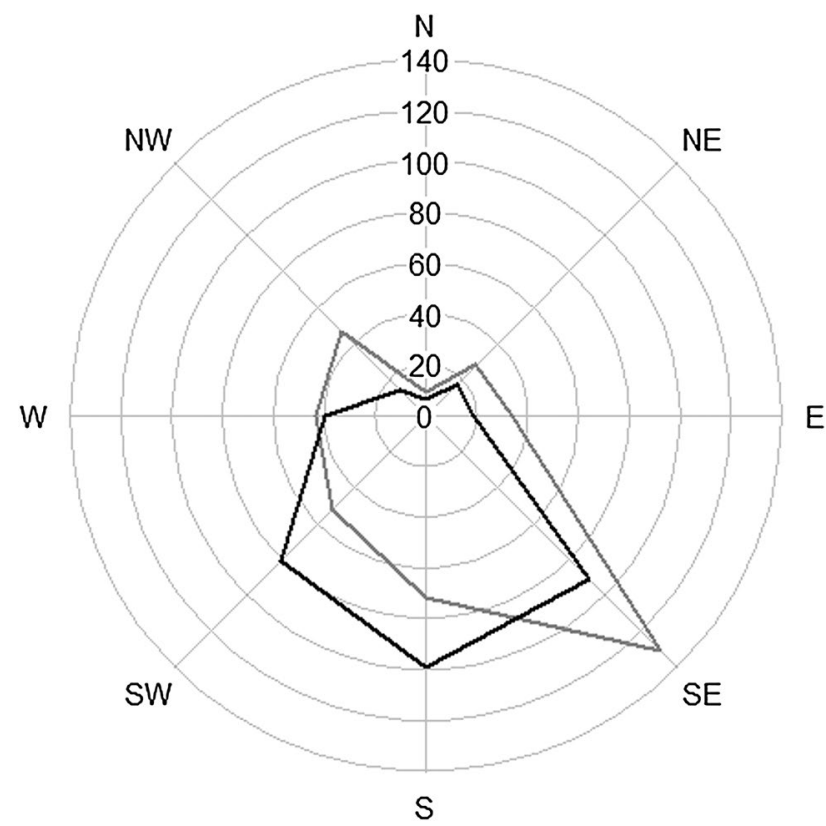

Fig. 3 Polar plot of the aspects of plants occupied (black line, $\mathrm{N}=367$ ) and unoccupied (grey line, $\mathrm{N}=416$ ) by Eriogaster catax in SW Poland zero, this variable did not affect site selection by ovipositing female. Nor was there also a significant difference in female preference between solitary plants and these located on the edge of hedgerows.

Hierarchical partitioning analysis revealed that sun exposure explained most of the variance in egg batches presence, followed by northness, position and plant species. The remaining variables showed independent contributions less than 5\% (Fig. 4).

The vertical position of the egg batches ranged from 27 to $248 \mathrm{~cm}$ above ground (median $=97 \mathrm{~cm}$, 1 st quartile $=75.5 \mathrm{~cm}, 2$ nd quartile $=127 \mathrm{~cm}, \mathrm{~N}=436$ ) and it was moderately correlated with height of host plant (Spearman rank correlation coefficient: $\left.r_{S}=0.63, P<0.01\right)$. Usually eggs were laid on the upper half of the host plant (median $=62.3 \%$ of plant height, 1 st and 3rd quartiles: 49.1 and $73.0 \%$, range: $19.8-97.4 \%, \mathrm{~N}=436$ ) and there was a weak but significant correlation between oviposition height as a proportion of the host plant height and the height of egg-bearing plants (Spearman rank correlation; $r_{S}=-0.19$, $P<0.001)$.

Among the 434 egg batches, more than half $(\mathrm{N}=244$, $56.2 \%)$ were laid on the trunk. Others were located on the branches at a distance of $0.1-230 \mathrm{~cm}$ from the trunk (median $=27.5 \mathrm{~cm}, 1 \mathrm{st}$ and 3rd quartiles: 11 and $49.5 \mathrm{~cm}$, $\mathrm{N}=188)$.

There was a significant difference in vertical (as height above ground) and horizontal (as distance from trunk) position of egg batches in relation to the position of the host plant (solitary vs. edge vs. interior) (Kruskal-Wallis Test, $\mathrm{H}_{2,436}=16.81, P<0.001$ and $\mathrm{H}_{2,433}=13.30, P=0.001$, respectively). Post hoc analysis revealed that inside of the shrub canopy females of E. catax laid their eggs in higher parts of host plant and closer to the trunk, than at the edge and on solitary plants (Fig. 5).

\section{Discussion}

\section{Oviposition preferences}

Our results indicate that females of $E$. catax select oviposition sites with a warm micro-climate, which confirm previous claims about thermophilic requirements of this species (Freina 1996; Höttinger 2005; Dolek et al. 2008; Oleksa 2012). This preference for warm micro-climate is revealed through the choice of plants exposed to direct sunlight and with a southern exposure. A similar preference for places with southern exposure also showed other researchers (Ruf et al. 2003; Höttinger 2005; Valchářová 2012). We also found some oviposition preference in a western facing-slope but its independent effect was apparently lower. In contrast to our results, studies conducted in the Czech Republic 
Fig. 4 Independent contributions (as a percentage of the total explained variance) of different parameters of host plant for the occurrence of the egg-batches, calculated using the hierarchical partitioning. All variables had a statistically significant $(P<0.05)$ impact on probability of egg batches presence

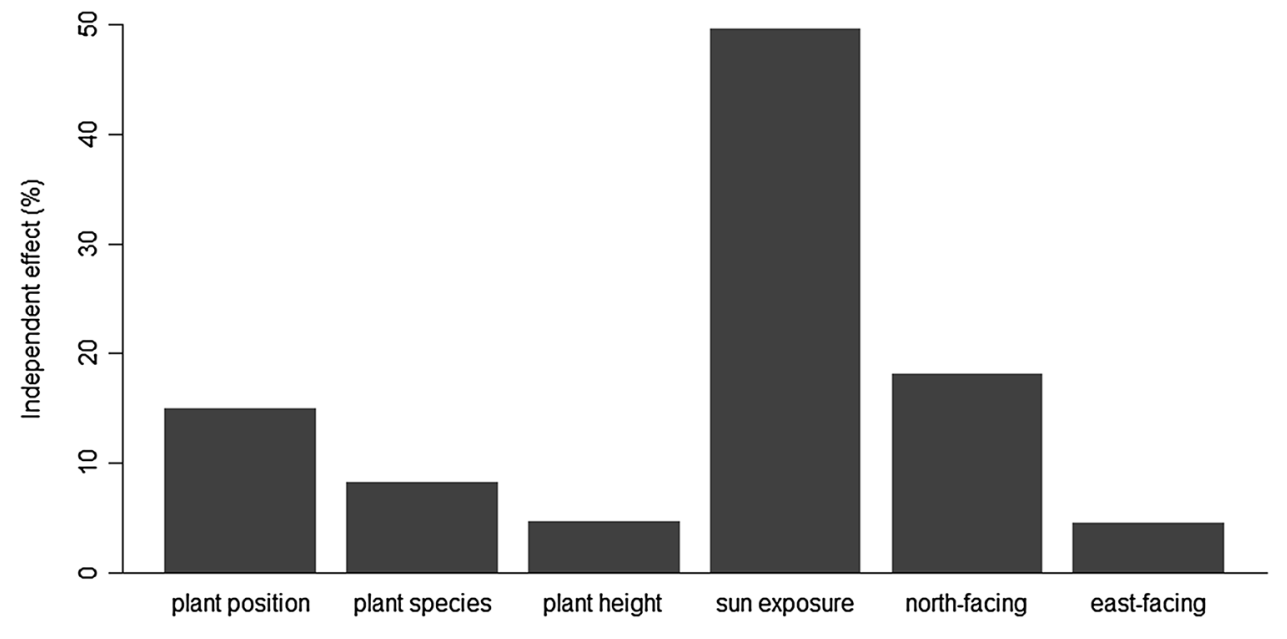

(a)

(b)

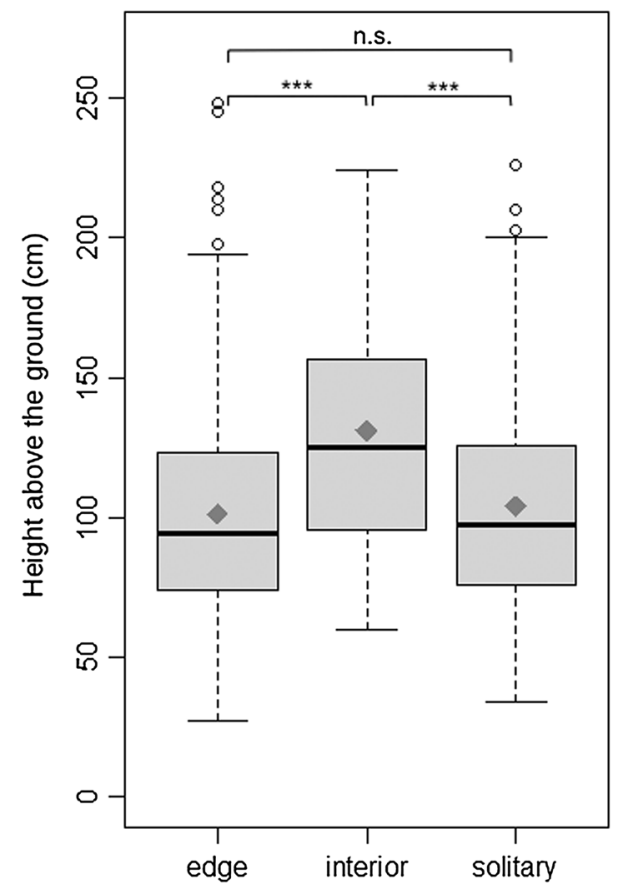

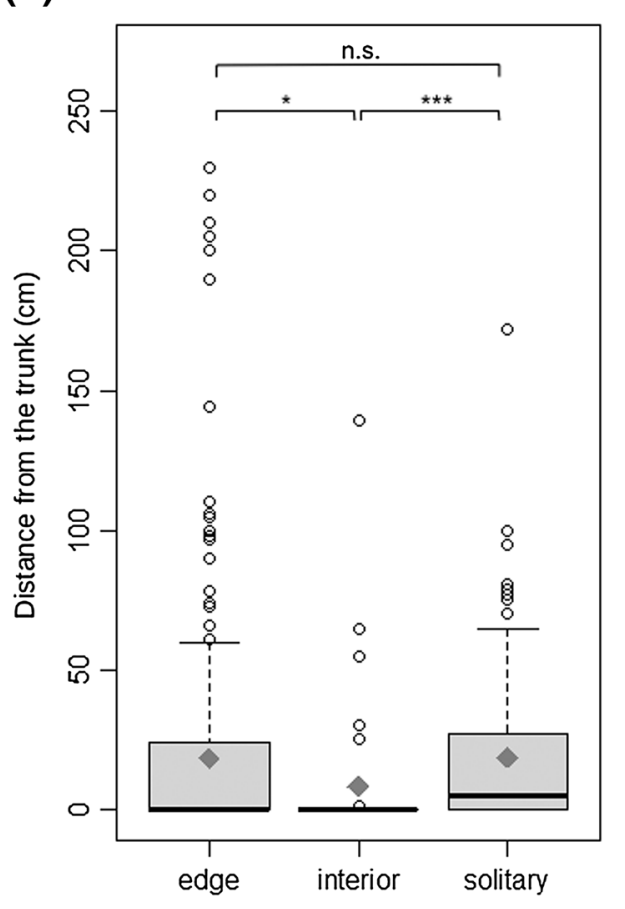

Fig. 5 Vertical (a) and horizontal (b) position of egg-batches of Eriogaster catax on the host plant in relation to position of occupied plant. Box plots show median (black horizontal line), 25th and 75th percentile (boundary of the box), nonoutlier ranges (whiskers), outliers and extremes (open circles) and mean (diamonds); MannWhitney $U$ test for significance: ${ }^{*} P<0.05,{ }^{*} * * P<0.001$, n.s. not significant have shown the avoidance of south-western exposure by the species (Valchářová 2012). The same studies also indicate inter-site differences in the insolation of occupied plants. In Bavaria (Germany) about $20 \%$ of the 114 larval webs had a western exposure and only $10 \%$ of them were recorded in southwest facing slopes (Dolek et al. 2008). Valchářová (2012) argues that the species prefers sunny and warm habitats, but avoids the extremely warm and dry microhabitats. It seems that the preference for south-west facing and wellinsolated sites may vary regionally in response to local climatic conditions. We can expect that at the northern limit of range of the species, including Poland, it should prefer sites with the warmest conditions at microhabitat level
(Fartmann and Timmermann 2006; Löffler et al. 2013). The species' preference for solitary plants or these located in peripheral parts of hedgerows found by us may also indicate importance of warm microclimatic conditions for ovipositing females. Loosely distributed and external plants receive more sunlight than these inside condensed stands. On the other hand, the preference of external plants can also be explained by their better accessibility for egg-laying females.

Accessibility also may be a reason for preference of the species for egg laying in outer surface of hedges and the differences in vertical position of egg batches in relation to the position of host plant. Inside of the dense shrub canopy, access to host plants is easier on the top, which can explain 
the higher location of laid eggs. Additionally, the higher egg deposition inside of the shrub canopy may be determined by thermal conditions related to better light penetration of upper parts of canopy. Differences in accessibility of host plants may also have an affect on horizontal position of egg batches. According to Ruf et al. (2003), the larval webs in E. catax is situated much deeper inside the shrub than in related species, as Eriogaster lanestris (L., 1758) or Malacosoma neustria (L., 1758), however it does not affect thermoregulation because blackthorns are still bare during the early development of the caterpillars and solar radiation easily reaches the larvae (Ruf et al. 2003). In our study egg batches were mainly located in the deeper parts of host plant, on the trunk or near to it. However, we found that on the edge of the shrub canopy and on loosely distributed host plants the more external parts of branches were used more often. This can be explained by their easier accessibility for ovipositing females, than in the case of shrubs positioned deeper in the canopy.

According to our results, plant species is also an important predictor for the occurrence of egg-batches. Blackthorn P. spinosa and pear tree Pyrus spp., were preferred as the host plant species for oviposition. Blackthorn is also considered the main host plant of this species in Poland (Oleksa 2012). However, analysis of other studies indicates that the preference for a host plant may vary regionally/locally. In Bavaria, Germany, for example, blackthorn were clearly preferred (Bolz 1998; Dolek et al. 2008), while in contrast to our results, in some countries, at least locally, females tend to choose hawthorn Crataegus spp. for oviposition (Höttinger 2005; García-Pérez et al. 2009; Valchářová 2012).

According to Dolek et al. (2008), differences in choice of plant species for oviposition may be an adaptation to different microclimatic conditions. In southern Europe, which is warmer, the species chose higher oviposition sites and thus hawthorn, with its greater height, is favoured over blackthorn. However, in the present study, the preferred egglaying plants were blackthorn and pear tree which, despite their varying abundance, were the most numerous species.

Only blackthorn was present in all sites and always it was the dominant species. It appears that the preference for a particular plant species can be conditioned by local availability of potential host plants. However our results indicate that microclimatic conditions are the most important ones.

\section{Conservation management}

Preserving suitable habitats, such as shrubs or hedgerows, is of primary importance for the conservation of $E$. catax. They are strongly affected by both agricultural intensification at various spatial scales (from increased application of agrichemicals or pesticides on local fields to loss of semi-natural and marginal habitats and decreased habitat heterogeneity at landscape level) (Benton et al. 2003; Geiger et al. 2010) as well as other human-related activities, e.g. road and railway verges management (Bernes et al. 2016). Agricultural intensification is considered to be a major driver of the decline of moths in Great Britain (Fox 2013). These type of habitats are also highly threatened in Poland, due to new legal regulations governing the removal of trees and shrubs. At the time of writing this paper, there is not required to have a special permission on cutting the shrubs or hedgerows growing on private land in cluster of up to $25 \mathrm{~m}^{2}$. This legal status is highly unfavourable for $E$. catax, since it might cause destruction of suitable oviposition sites, including (according to our findings) preferredloosely growing host plants.

An important element of the species conservation is also appropriate management of host plant resources. Preferences of ovipositing females for peripheral parts of hedgerows makes the annual mechanic trimming of such structures (e.g. roadside shrubs) a very serious threat to E. catax. In the case of another species laying eggs on outer surface of hedgerows, the Brown hairstreak Thecla betulae, it considerably increases mortality in the population by removing even more than $90 \%$ of the eggs laid (Merckx and Berwaerts 2010). We do not have such data for E. catax, however, taking into account the similarity of ecological requirements of both species, we can expect that this type of activity may also result in a high mortality rate. It can make that preferred habitats will become an 'ecological trap' for the species. Modelling the impact of differing hedgerow-cutting regimes, showed that a scenario of annual cutting of all hedgerows and woodland edges would cause a population of $T$. betulae to go extinct in only 3 years (Merckx and Berwaerts 2010). In Poland, in opposite to the UK there is no special guideline like Entry Level Stewardship (ELS) Agri-Environment Schemes (AES) that describes the options hedgerows cutting regime. In England, the majority of hedgerows managed under AES are cutting once every 2 years in autumn, and in Scotland even once in 3 years (Fuentes-Montemayor et al. 2011; Staley et al. 2012). According to Staley et al. (2016) late winter cutting would be generally beneficial for hedgerow Lepidoptera, although some species, as abovementioned $T$. betulae, may be disadvantaged by this. This solution can't be applied for E. catax since females start to lay eggs in late September, and then eggs overwinter on shrubs until April (Bolz 1998; Oleksa 2012). For this reason late summer trimming would be better for this species. This kind of practice would allow for protection of the eggs before to be cut off or destroyed during flailing in the winter time. Surely, decreasing the intensity of hedgerow trimming is preferable in case of oviposition habitats of $E$. catax. For shrub-feeding butterflies, such as $T$. betulae and Satyrium spini, a rotational trimming of a quarter of the shrubs every fourth year was also recommended (Fartmann 
and Timmermann 2006; Löffler et al. 2013; Helbing et al. 2015). It seems that this solution may also be appropriate to reduce the heavy egg losses in case of E. catax.

Cutting down shrubs is one of the major threats for $E$. catax, as it is directly linked with habitat destruction. This issue should be also considered in the management of the species' habitat and its local population. Thus, before cutting potential food plants to ground level ,professional inspections should be carried out to exclude presence of eggs or caterpillars. This recommendation should be implemented from late September to the end of May, when clutches of eggs or caterpillars can be present on the shrubs.

The results of our research may also be important in the planning of translocation programs to preserve populations threatened by habitat destruction (e.g. Kuźmiński et al. 2014), indicating which environmental factors should be taken into account when choosing a relocation destination as well as which parts of the host plant should be particularly taken into account when searching for the species. It should be noted that we are not fully convinced of the effectiveness of the caterpillars translocation (Kuźmiński et al. 2014), especially in dense shrub canopy. Of course, we agree with better sighting of caterpillars and their webs than eggs, but from our point of view, it is unlikely that all caterpillars would be collected, especially, when they are instars L3-L4 when they are spread around all over the bush. In this situation they can be overlooked, damaged or simply lost. Moreover, collecting feeding caterpillars is difficult because of their specific behavior-we have observed on numerous occasion that caterpillars have fallen down under the bush when they were in danger. In particular, it may be difficult to collect caterpillars from deeper parts of hedgerows where, as our results show, the larval webs may be placed in higher parts of the host plant. These considerations should be taken into account at the planning stage of this type of work.

Results of our analysis are the basis for better understanding of the ecological requirements of $E$. catax that are crucial to the effective management and conservation of the species. We are aware that some important aspects of the biology and ecology of E. catax are yet to be studied, e.g. species' dispersal abilities and habitat preferences at the landscape scale. It may be also interesting to examine the usefulness of $E$. catax as an umbrella species, based on studies of species co-occurring. However, we believe that certainly this species could be used as 'flagship' for the conservation of semi-natural field margins in agricultural landscapes.

Acknowledgements We are grateful to Deborah Harvey for reading this manuscript and commenting on it and to anonymous reviewers who provided valuable feedback to help us improve the manuscript. Special thanks are given to Dr. Thomas Fartmann (Osnabrück University) for constructive advice and help during publishing process. The research was supported by the Department of Invertebrate Biology, Evolution and Conservation, Institute of Environmental Biology,
Faculty of Biological Science, University of Wrocław (project no. 1076/S/IBŚ/2017).

\section{Compliance with ethical standards}

Conflict of interest On behalf of the Authors I confirm that there is no conflict of interest in case of the manuscript. Moreover, the authors have declared that no competing interests exist.

Open Access This article is distributed under the terms of the Creative Commons Attribution 4.0 International License (http://creativecommons.org/licenses/by/4.0/), which permits unrestricted use, distribution, and reproduction in any medium, provided you give appropriate credit to the original author(s) and the source, provide a link to the Creative Commons license, and indicate if changes were made.

\section{References}

Anthes N, Fartmann T, Hermann G (2008) The Duke of Burgundy butterfly and its dukedom: larval niche variation in Hamearis lucina across Central Europe. J Insect Conserv 12:3-14. https:// doi.org/10.1007/s10841-007-9084-7

Baillet Y (2013) Inventaire et suivi de Eriogaster catax (Laineuse du Prunellier) sur l'ENS des Communaux de Trept (Isère). Rapport d'étude de Flavia A.D.E. Trept

Bartoń K (2016) MuMIn: multi-model inference. R package version 1.15.6. http://CRAN.R-project.org/package=MuMIn

Bates D, Mächler M, Bolker B, Walker S (2015) Fitting linear mixedeffects models using lme4. J Stat Softw 67:1-48. https://doi. org/10.18637/jss.v067.i01

Benton TG, Vickery JA, Wilson JD (2003) Farmland biodiversity: is habitat heterogeneity the key?. Trends Ecol Evol 18:182-188. https://doi.org/10.1016/S0169-5347(03)00011-9

Bernes C, Bullock JM, Jakobsson S et al (2016) How are biodiversity and dispersal of species affected by the management of roadsides? A systematic map protocol. Environ Evid. https://doi.org/10.1186/ s13750-016-0055-x

Bolz R (1998) Zur Biologie und Ôkologie des Heckenwollaft ers Eriogaster catax (Linnaeus, 1758) in Bayern (Lepidoptera: Lasiocampidae). Nachrichten Entomol Ver Apollo NF 18:331-340

Burnham KP, Anderson DR (2002) Model selection and multimodel inference a practical information-theoretic approach. Springer, New York

Bury J (2015) New data on occurrence of Eriogaster catax (Linnaeus, 1758) (Lepidoptera: Lasiocampidae) in south-eastern part of Poland. Acta Entomol Silesiana 23:1-10

Cade BS (2015) Model averaging and muddled multimodel inferences. Ecology 96:2370-2382. https://doi.org/10.1890/14-1639.1

Čelik T (2013) Oviposition preferences of a threatened butterfly Leptidea morsei (Lepidoptera: Pieridae) at the western border of its range. J Insect Conserv 17:865-876. https://doi.org/10.1007/ s10841-013-9567-7

Čelik T, Bräu M, Bonelli S et al (2015) Winter-green host-plants, litter quantity and vegetation structure are key determinants of habitat quality for Coenonympha oedippus in Europe. J Insect Conserv 19:359-375. https://doi.org/10.1007/s10841-014-9736-3

Chevan A, Sutherland M (1991) Hierarchical partitioning. Am Stat 45:90-96. https://doi.org/10.1080/00031305.1991.10475776

Chrzanowski A, Kuźmiński R, Łabędzki A et al (2013) Occurrence of Eriogaster catax (Linnaeus, 1758) (Lasiocampidae, Lepidoptera) 
and the proposed protective actions on the Polish territory. Sci Nat Technol 7:1-7

Council of the European Communities (1992) Council Directive 92/43EEC of 21. May 1992 on the conservation of natural habitats and of wild fauna and flora. Off J Eur Commun 35:7-50

de Heer M, Kapos V, ten Brink BJE (2005) Biodiversity trends in Europe: development and testing of a species trend indicator for evaluating progress towards the 2010 target. Philos Trans R Soc B 360:297-308. https://doi.org/10.1098/rstb.2004.1587

Dolek M, Freese-Hager A, Geyer A, Liegl A (2008) Die Habitatbindung von Maivogel und Heckenwollafter: Ein Vergleich von zwei Lichtwaldarten. Ökologische Bedeutung und Schutz von Mittelwäldern in Bayern, Bayerisches Landesamt für Umwelt, pp 38-55

Dormann CF, Elith J, Bacher S et al (2013) Collinearity: a review of methods to deal with it and a simulation study evaluating their performance. Ecography 36:27-46. https://doi. org/10.1111/j.1600-0587.2012.07348.x

Dover J, Sparks T (2000) A review of the ecology of butterflies in British hedgerows. J Environ Manage 60:51-63. https://doi. org/10.1006/jema.2000.0361

EIONET (2014) Species assessments at EU biogeographical level. http://art17.eionet.europa.eu/article17/reports2012. Accessed 23 Oct 2016

Fartmann T, Timmermann K (2006) Where to find the eggs and how to manage the breeding sites of the Brown Hairstreak (Thecla betulae (Linnaeus, 1758)) in Central Europe? Nota Lepidopterol 29:125

Forman RTT, Baudry J (1984) Hedgerows and hedgerow networks in landscape ecology. Environ Manage 8:495-510. https://doi. org/10.1007/BF01871575

Fox R (2013) The decline of moths in Great Britain: a review of possible causes: The decline of moths in Great Britain. Insect Conserv Divers 6:5-19. https://doi. org/10.1111/j.1752-4598.2012.00186.x

Freina JJ de (1996) Eriogaster catax (Linnaeus, 1758). In: Helsdingen PJ, van Willemse L, Speight MCD (eds) Background information on invertebrates of the habitat directive and the bern convention. Part I: Crustaceae, Coleoptera and Lepidoptera. Nature and Environment No. 79. pp 117-120

Fuentes-Montemayor E, Goulson D, Park KJ (2011) The effectiveness of agri-environment schemes for the conservation of farmland moths: assessing the importance of a landscapescale management approach: effects of agri-environment schemes on moths. J Appl Ecol 48:532-542. https://doi. org/10.1111/j.1365-2664.2010.01927.x

Galipaud M, Gillingham MAF, David M, Dechaume-Moncharmont F-X (2014) Ecologists overestimate the importance of predictor variables in model averaging: a plea for cautious interpretations. Methods Ecol Evol 5:983-991. https://doi. org/10.1111/2041-210X.12251

García-Pérez B, Pajarón JL, Quintanilla AM, Munguira ML (2009) Datos Sobre la Biología de Eriogaster catax (Lepidoptera: Lasiocampidae) Y Nuevas Citas de Cantabria, España. Bol Soc Entomológica Aragon 44:157-160

Geiger F, Bengtsson J, Berendse F et al (2010) Persistent negative effects of pesticides on biodiversity and biological control potential on European farmland. Basic Appl Ecol 11:97-105. https:// doi.org/10.1016/j.baae.2009.12.001

Gelman A (2008) Scaling regression inputs by dividing by two standard deviations. Stat Med 27:2865-2873. https://doi.org/10.1002/ $\operatorname{sim} .3107$

Gelman A, Su Y-S (2015) arm: data analysis using regression and multilevel/hierarchical models. R package version 1.8-6. http:// CRAN.R-project.org/package $=$ arm
Giam X, Olden JD (2016) Quantifying variable importance in a multimodel inference framework. Methods Ecol Evol 7:388-397. https://doi.org/10.1111/2041-210X.12492

Głowicki B, Otop J, Urban G, Toruczyński K (2005) Klimat. In: Opracowanie ekofizjograficzne dla województwa dolnośląskiego. WBU, Wrocław, pp 53-62

Grueber CE, Nakagawa S, Laws RJ, Jamieson IG (2011) Multimodel inference in ecology and evolution: challenges and solutions: multimodel inference. J Evol Biol 24:699-711. https://doi. org/10.1111/j.1420-9101.2010.02210.x

Guisan A, Weiss SB, Weiss AD (1999) GLM versus CCA spatial modeling of plant species distribution. Plant Ecol 143:107-122. https://doi.org/10.1023/A:1009841519580

Halada L, Evans D, Romão C, Petersen J-E (2011) Which habitats of European importance depend on agricultural practices? Biodivers Conserv 20:2365-2378. https://doi.org/10.1007/ s10531-011-9989-z

Helbing F, Cornils N, Stuhldreher G, Fartmann T (2015) Populations of a shrub-feeding butterfly thrive after introduction of restorative shrub cutting on formerly abandoned calcareous grassland. J Insect Conserv 19:457-464. https://doi.org/10.1007/ s10841-015-9766-5

Henle K, Alard D, Clitherow J et al (2008) Identifying and managing the conflicts between agriculture and biodiversity conservation in Europe: a review. Agric Ecosyst Environ 124:60-71. https:// doi.org/10.1016/j.agee.2007.09.005

Höttinger H (2005) Der Hecken-Wollafter (Eriogaster catax L.) in Wien (Lepidoptera: Lasiocampidae). Endbericht einer Studie im Auftrag der Wiener Magistratsabteilung MA 22 (Umweltschutz), Wien

Johnson PCD (2014) Extension of Nakagawa \& Schielzeth's R2GLMM to random slopes models. Methods Ecol Evol 5:944946. https://doi.org/10.1111/2041-210X.12225

Kuussaari M, Singer M, Hanski I (2000) Local specialization and landscape-level influence on host use in an herbivorous insect. Ecology 81:2177-2187

Kuźmiński R, Malkiewicz A, Mazur A (2014) Translocation of threatened localities of Eastern eggar Eriogaster catax as a method of active species protection based on localities in Southern Wielkopolska. Acta Sci Pol 13:15-23

Lemon J (2006) Plotrix: a package in the red light district of R. R-News 6:8-12

Löffler F, Stuhldreher G, Fartmann T (2013) How much care does a shrub-feeding hairstreak butterfly, Satyrium spini (Lepidoptera: Lycaenidae), need in calcareous grasslands? Eur J Entomol 110:145-152

Matson PA, Parton WJ, Power AG, Swift MJ (1997) Agricultural intensification and ecosystem properties. Science 277:504-509. https://doi.org/10.1126/science.277.5325.504

Merckx T, Berwaerts K (2010) What type of hedgerows do Brown hairstreak (Thecla betulae L.) butterflies prefer? Implications for European agricultural landscape conservation. Insect Conserv Divers. https://doi.org/10.1111/j.1752-4598.2010.00088.x

Nakagawa S, Schielzeth H (2013) A general and simple method for obtaining $R^{2}$ from generalized linear mixedeffects models. Methods Ecol Evol 4:133-142. https://doi. org/10.1111/j.2041-210x.2012.00261.x

Oleksa A (2002) Występowanie Eriogaster catax (Linnaeus, 1758) (Lepidoptera: Lasiocampidae) w Polsce. Przegląd Przyr 12:103-106

Oleksa A (2004) Eriogaster catax (Linnaeus, 1758): barczatka kataks. In: Głowaciński Z, Nowacki J (eds) Polska czerwona księga zwierząt. Bezkręgowce. IOP PAN, Akademia Rolnicza im. A. Cieszkowskiego, Kraków-Poznań

Oleksa A (2012) 1074 Barczatka kataks Eriogaster catax (Linnaeus, 1758). In: Makomaska-Juchiewicz M, Baran P (eds) Monitoring 
gatunków zwierząt. Przewodnik metodyczny. GIOŚ, Warszawa, pp 106-123

R Core Team (2016) R: a language and environment for statistical computing. Vienna: R Foundation for Statistical Computing. http://www.R-project.org/

Refsnider JM, Janzen FJ (2010) Putting eggs in one basket: ecological and evolutionary hypotheses for variation in ovipositionsite choice. Annu Rev Ecol Evol Syst 41:39-57. https://doi. org/10.1146/annurev-ecolsys-102209-144712

Reif J, Voříšek P, Šlastný K et al (2008) Agricultural intensification and farmland birds: new insights from a central European country: agricultural intensification and farmland birds. Ibis 150:596-605. https://doi.org/10.1111/j.1474-919X.2008.00829.x

Ruf C, Freese A, Fiedler K (2003) Larval Sociality in three species of central-place foraging lappet moths (Lepidoptera: Lasiocampidae): a comparative survey. Zool Anz J Comp Zool 242:209-222. https://doi.org/10.1078/0044-5231-00099

Staley JT, Sparks TH, Croxton PJ et al (2012) Long-term effects of hedgerow management policies on resource provision for wildlife. Biol Conserv 145:24-29. https://doi.org/10.1016/j. biocon.2011.09.006

Staley JT, Botham MS, Chapman RE et al (2016) Little and late: how reduced hedgerow cutting can benefit Lepidoptera. Agric Ecosyst Environ 224:22-28. https://doi.org/10.1016/j.agee.2016.03.018

Stoate C, Báldi A, Beja P et al (2009) Ecological impacts of early 21st century agricultural change in Europe: a review. J Environ Manage 91:22-46. https://doi.org/10.1016/j.jenvman.2009.07.005

Tryjanowski P, Hartel T, Báldi A et al (2011) Conservation of farmland birds faces different challenges in Western and Central-Eastern Europe. Acta Ornithol 46:1-12. https://doi.org/10.3161/000164 511X589857

Tscharntke T, Klein AM, Kruess A et al (2005) Landscape perspectives on agricultural intensification and biodiversity: ecosystem service management. Ecol Lett 8:857-874. https:// doi.org/10.1111/j.1461-0248.2005.00782.x

Valchářová J (2012) Vyhodnocení monitoringu evropsky významného druhu Eriogaster catax (Lepidoptera). BSc. Thesis, University of South Bohemia

Walsh C, Mac Nally R (2013) hier.part: hierarchical partitioning. R package version 1.0-4. https://CRAN.R-project.org/package=hier. part

Wehling S, Diekmann M (2009) Importance of hedgerows as habitat corridors for forest plants in agricultural landscapes. Biol Conserv 142:2522-2530. https://doi.org/10.1016/j.biocon.2009.05.023

World Conservation Monitoring Centre (1996) Eriogaster catax. The IUCN Red List of Threatened Species 1996: e.T8029A12883403. http://dx.doi.org/10.2305/IUCN.UK.1996. RLTS.T8029A12883403.en. Accessed 28 Feb 2017

Wuczyński A, Kujawa K, Dajdok Z, Grzesiak W (2011) Species richness and composition of bird communities in various field margins of Poland. Agric Ecosyst Environ 141:202-209. https://doi. org/10.1016/j.agee.2011.02.031

Wuczyński A, Dajdok Z, Wierzcholska S, Kujawa K (2014) Applying red lists to the evaluation of agricultural habitat: regular occurrence of threatened birds, vascular plants, and bryophytes in field margins of Poland. Biodivers Conserv 23:999-1017. https://doi. org/10.1007/s10531-014-0649-y

Zechmeister H, Tribsch A, Moser D, Wrbka T (2002) Distribution of endangered bryophytes in Austrian agricultural landscapes. Biol Conserv 103:173-182. https://doi.org/10.1016/ S0006-3207(01)00119-7

Zuur AF, Ieno EN, Elphick CS (2010) A protocol for data exploration to avoid common statistical problems: data exploration. Methods Ecol Evol 1:3-14. https://doi. org/10.1111/j.2041-210X.2009.00001.x 